\title{
Sustainability Issues in Brazilian Housing Construction Industry: The Role of Workers' Education
}

\author{
Carla Caprara Parizi, Irenilza de Alencar Nääs, Solimar Garcia, \\ Eder Moreno Ferragi, and Denise Simões Dupont Bernini \\ Paulista University-UNIP, Graduate Program in Production Engineering, \\ Dr. Bacelar St. 1212, São Paulo, Brazil \\ irenilza@gmail.com
}

\begin{abstract}
Brazilian housing industry is a sector that employs a large number of workers without specific technical skill or training. This contributes to the increase in waste of materials due to the limited use of new technologies. The workers low education level interferes in an effort to enhance and improve the sustainability indices in Brazil, in this business chain, which grew up about $4 \%$ per year, in the last two years. This study aimed to analyze the issues related to the sustainability of Brazilian housing industry. We compared the data from developed and developing countries, and results indicated that the amount of waste generated by residential constructions is positively correlated to illiteracy. Data on overall waste range from 10 to $30 \%$, depending on the region, and most of it is related to lack of labor training. Improvements in this sector are needed in order to meet the sustainability demand.
\end{abstract}

Keywords: construction supply chain, education, professional training.

\section{Introduction}

The construction supply chain represents nearly $9 \%$ of Brazil's GDP, and it increased $4 \%$ from 2010 to 2011 . The construction industry is highly demanding of labor and medium size retail businesses, and it involves a large number of small contractors. It is a growing sector as the national statistics data show an increase of 2.7 million new homes between 2009 and 2011 [1; 11]. The sustainability concepts within the housing construction industry, however, bring up some issues primarily related to the large amounts of wastes generated during the building process. There are also other issues, amongst them we can highlight the reduction in permeability of the soil, changing in drainage methods, which can cause flooding and reduce groundwater reserves; the use of illegal wood, and the improper disposal of effluents [1].

This is a relatively informal business sector, which represents a significant challenge for achieving sustainability within the process as not all steps are properly traced. Probably one of the most influential inhibitions of reducing of wastes and improving sustainability in this industry is the poor training of human resources. Dealing with aspects of sustainability it requires proper understanding of construction 
management and the use of different types of materials and components in the various stages of operation $[21 ; 22]$. The lack of innovation in products and processes, in the supply chain, make things more difficult in achieving sustainability in this sector, and it involves designers, manufacturers, facility managers and consumers who seek a more sustainable building. May we emphasize that residential construction industry is probably one of the Brazilian industries that developed less, when compared to other industrial sectors in the last years.

Although facing this scenario, there has been some progress regarding primary education of Brazilian professionals involved in construction, in recent years. According to data from the Annual Social Information of the Ministry of Labor and Employment (RAIS) the percentage of illiterates in the construction sector decreased by $60 \%$ in 9 years, from nearly 30 thousand workers (in a total of 1 million workers) in 2000 to approximately 23 thousand (in a total of 2 million in 2009). Despite the lack of official statistical data, organizations related to the Brazilian construction industry indicate that the improvement in education contributes to improve labor quality of life as it reduces the amount of accidents increases work efficiency and provides the reduction in waste and losses, in the construction sites [4].

This study aimed to analyze the issues related to the Brazilian residential construction industry, mainly those associated to the training of workers in order to minimize losses in the construction process.

\section{$2 \quad$ Methodology}

An extensive literature review was done on the field of residential construction industry. Data were collected from previous studies including the various phases of the construction process $[1 ; 8 ; 11 ; 12 ; 19 ; 24]$.

The following questions were unfolded:

1. Is the lack of basic education a factor for increasing waste, hence the lack of sustainability in the construction process? And,

2. Does the investment in basic education (formal or technical training) improve this scenario?

We studied data from the organizations affiliated to the construction sectors $[1 ; 8$; $19 ; 24]$, and information on illiteracy (mean value from 2003-2010) were searched on regular education at governmental database, and the World Bank Report [12; 27]. GDP ( $\%$ of the construction industry) data from the studied countries were obtained from [27].

As innovative initiatives are stated as an instrument of waste reduction, and it impact positively in the sustainable construction process, the following innovations used in the residential buildings were selected: 1- the use of new materials (cardboard, drywall), 2- the use of alternative source of energy (solar energy), 3- the adoption of water use reduction devices, 4- the adoption of fluorescent or LED bulb lamps in the project, and 5- broader structure of the sector supply chain. Scores were given from 0 to $2(0=$ none innovation is adopted; $1=1$ to 3 innovations are adopted; $2=$ all five innovations are adopted) according to the degree of adoption of the initiatives by the 
different countries, from 1 to 5. A table was built comparing the data from the countries Brazil, Spain, United Kingdom, Portugal, Turkey, China and Japan. Pearson's correlation was applied to the values in order to determine the relationship between the percentage of residential construction waste, and the country' GDP, illiteracy (\%), and the level of adoption of innovation in residential buildings.

\section{Results and Discussion}

\subsection{Waste in the Construction Process}

Generating waste is one of the main issues in the Brazilian construction industry; it consists, not just by rejected materials at the construction site, but also by losses during the building process. Wastes are inevitable when they happen by natural accidents. Losses during construction can be classified according to their control (avoidable and unavoidable) according to their nature (overproduction; substitution; waiting for, transportation, processing, inventory, the production of defective products, and others such as theft, vandalism, and accidents), to their origin in the production process, and, finally, to the processes that precede the manufacturing of materials, such as the development of human resources, design, procurement and planning [5; 9].

It is known that one of the main sources of wastage in construction today is the lack of planning on recruiting skilled labor. This lead construction engineers to increase the number of workers in order to avoid the risk of the work stops due to lack of staff [4]. Nevertheless, losses of material are positively related to waste in materials. They can be seen as unnecessary consumption of material, which results in excessive waste production as it involves future availability of materials, power demand in producing these materials, and it is related to losses in material transportation $[2 ; 3 ; 13]$.

More recently, the construction waste was studied on the national level, where 85 worksites were surveyed from 75 construction companies in 12 Brazilian states, assessing consumption and losses related to 18 different types of materials and services. The research found a wide range of performance amongst the companies, from minimum losses $(2.5 \%)$, which are similar to the best international rates, to an alarming amount of waste (133\%), probably due to many mistakes committed during the construction process. There was also noted that there were differences within the same company and from one service to another. The study showed that, on average, the waste is near $10 \%$, although it was believed to be near $30 \%$ [2]. Similar study carried out in the Northeastern of Brazil indicated that the loss ratio of construction material were mostly on sand (72\%), gravel $(17 \%)$, cement $(18 \%)$, and concrete and steels around $11 \%[15 ; 23]$. Amongst the reasons attributed to these losses there are poor transportation of material, lack of adequate equipment in the construction site, improper use of machinery to produce concrete and lack of a standardized method for receiving, controlling, storing, and transporting materials. 
This information is quite different from that of developed countries. In the UK, a study was conducted with architects and contractors with the purpose of pointing attitudes to waste minimization, revealed that although many are the causes of wastes during the construction; the designer has a key role in the prevention and waste minimization [17]. The study divides into two parts to be analyzed during the first and second stage of the project (the project and the building). Although the study does not disclose the percentage or proportion of each stage of the total loss or wastage in construction, it reveals that the major source of waste is in the design stage, and it happens mostly related to the last-minute changes due to customer requests, followed by the lack in detailing and specifications. Regarding the stage of construction, where there is the action of the least skilled workers, the leading causes of wastage presented were the remnants cuttings, materials and products used, misapplication of materials, and improper storage methods $[18 ; 17]$.

When comparing the data from different countries, the waste generated during the residential building was found to be positively correlated to the percentage of illiteracy (0.761), while it was inversely correlated to both GDP (-0.240) and the use of innovation during the construction $(-0.767)$ as seen in Table 1.

Table 1. Comparison between the percentage of waste generated in residential constructions, GDP, illiteracy and adoption of innovation in construction, in developed and developing countries

\begin{tabular}{lcccc}
\hline Country & $\begin{array}{c}\text { GDP } \\
(\mathbf{\%})\end{array}$ & $\begin{array}{c}\text { Waste } \\
(\mathbf{\%})\end{array}$ & $\begin{array}{c}\text { Illiteracy } \\
(\mathbf{\%}) *\end{array}$ & $\begin{array}{c}\text { Use of innovation } \\
(\mathbf{\%} ; \mathbf{0 , 1}, \mathbf{2})\end{array}$ \\
\hline Brazil & 4.0 & 10.0 & 11.0 & 0 \\
Spain & 7.0 & 3.0 & 2.0 & 1 \\
United Kingdom & 7.0 & 2.0 & 1.0 & 2 \\
Portugal & 5.5 & 3.0 & 5.0 & 1 \\
Turkey & 5.0 & 5.0 & 13.0 & 0 \\
China & 12.0 & NA & 9.0 & 0 \\
Japan & 9.0 & NA & 1.0 & 2 \\
\hline Pearson & -0.240 & 1 & 0.761 & -0.767 \\
coefficient & & & &
\end{tabular}

* Mean values from $2003-2010$.

A study on the levels of use of sustainability indicators between Brazilian, Portuguese and American construction industries pointed out that Portugal has more detailed set of disclosure of social, economic and environmental statistics than the other two countries [22]. Another approach is that social responsibility may also be seen inside the sustainability principles and conceptualizes as the willingness of a company to contribute to a better society and a cleaner environment $[21 ; 6]$. Brazilian companies should disclose their information on their websites about sustainability and emphasize the importance given to this issue as done in other countries. 
Several methodologies were found for identifying the systematic approach for dealing with potential adverse environmental impacts at the construction stage. Some are presented as an assessment tool, to measure the environmental performance of construction activities, and it covers various categories of environmental aspects such as atmospheric emissions; water emissions; waste generation; soil alteration; resource consumption; local issues; transport issues; effects on biodiversity; and incidents, accidents and potential emergency situations [25]. In any case, the main environmental focus regarding this issue should be the prevention and reduction of construction waste generation during the residential construction [7].

\subsection{How May the Worker' Education Change the Process?}

There was a significant development of the Brazilian construction industries since the 90s, although there was a significant delay when compared with other industries. Facing the new demands of environmental and social responsibility the industry could not ignore the investment in proper training in order to educate their hand labor. Therefore, qualify with these new challenges, means more than just to learn production processes of construction, but also to understand the whole process, and the impact that certain actions or lack of them affect both nature and society [16]. Brazil has near 100 thousand legal construction companies employing around 2 million legal workers, including masons, carpenters, technicians, engineers, and architects. There is also a large number of informal workers, which according to [8] is about 4 million.

Brazil still lives in a profound social inequality, which can be assessed by the level of functional illiteracy (citizens with less than 4 years of formal studies) representing a total of $29 \%$ of Brazilians [12]. The illiterates citizens, who cannot read or write a coherent message in Portuguese reaches $13 \%$ of the total population of persons 15 years or older, affecting the number of workers in various activities [11]. According to the Brazilian Chamber of Construction Industry, in 2009, the relative percentage of jobs in the construction business was 7\%, i.e. from 96 million employed Brazilians, more than 6 million were related to the construction industry [12]. In this scenario, there is the proposed federal government construction program so-called "Construction for Citizenship" which had amongst the goals, to reduce illiteracy of construction workers in their own work area, the construction sites. In doing this, it induces the necessary conditions for the professionalization action and full citizenship of this worker [25;20].

Much of the current construction workers develop their skills by observing experienced colleagues, and they learn by repetition. As the process of repetition does not necessarily always reproduce right actions, sometimes it brings the use of poor practices. Although the construction industry fulfill a social responsibility when it employs less educated labor, it generates low productivity, waste and rework, and high rates of accidents when employing low skilled workers. There is an effect of education on the onset of labor accidents [23;25]. The authors report that $60 \%$ of the victims had between 1 to 4 years in school, and $36 \%$ had 5-9 years in primary education. In this study, only $4 \%$ of the workers had more than 10 years of education. 
It was also noted that $44 \%$ of workers had 5-9 years of study and, from this amount, only $24 \%$ had some accident at work. From the number of workers (55\%) with 1 to 4 years of formal education, only $32 \%$ of them have suffered some accident at work. This means that as the time in school increased the accidents in the work was reduced. This is the main challenge Brazilian residential construction activity has to face when meeting the demand of 28 million housing units by 2023, planned by the National Housing Plan [20].

Illiteracy was found to be positively correlated to the waste generation (Table 1) while the increase in the use of innovation decreases the amount waste (correlation of -0.767). However, the use of innovative techniques can only be applied appropriately if the workers have a certain level of education and training. One key aspect of the improvement in the construction industry is the investment in education and training of workers. Less educated workers without being able to use innovative tools may hinder their potential in producing work of quality [2]. The deficiency in reliable information is also a key factor in understanding this issue. Most construction companies do not give their actual numbers which makes it difficult for collecting data.

In order to improve Brazilian context in the Human Development Index (HDI) the government should invest in infrastructure, sanitation and housing at annual rates of $21.4 \%$. The cities spend more than $50 \%$ of world energy sources with all its complexities [14]. The construction sector consumes $40 \%$ of the natural resources, $40 \%$ of energy and generates $40 \%$ of waste $[2 ; 16]$. Therefore, to achieve sustainability, several practices need to be adopted by the construction industry.

\section{$4 \quad$ Final Remarks}

The concepts of sustainable residential construction are focused on processes that favored the use of natural factors such as natural light, heat, ventilation, among others, which were abandoned with the advent of electricity and artificial heating and cooling. These concepts need to be concentrated on the lifecycle of the project, and the process of reuse of material, besides minimizing wastes in the residential construction cycle.

Several issues are involved in the Brazilian residential construction industry which may affect the sustainability of the construction process. Amongst them, there are the proper regulation, and workers education and training. Implementing appropriate actions related to those two items would increase today's incipient applications of sustainability principles in this industry in most developing countries.

\section{References}

1. ABRAMAT - Associação Brasileira da Indústria da Construção. 2012. Perfil da Cadeia Produtiva da Construção e da Indústria de Materiais e Equipamentos (2012),

http: / / www . abramat. org.br/site/lista.php? secao=9 (accessed on: March 2013) 
2. Agopyan, V.: Melhor que Parece - Entrevista concedida a Simoni Capozzi. Revista Construção, São Paulo (2686), 6-11 (1999)

3. Baqueiro, J.A.B., Carreiro, A.A.A.: difícil comunicação entre a gerência e o operário de baixa escolaridade na construção civil (2008), http://info.ucsal.br/banmon/ mostra_dados_doc.php? Seq=166\&Pag=0\&Doc=3 (accessed on: March 2013)

4. CBI em pauta - 08/09/2010, http: / /www. cbic.org.br/informativos/cbicem-pauta/setor-da-construcao-muda-o-perfil-dos-seustrabalhadores-e-esta-perto-de- (accessed on: March 2013)

5. Colombo, C.R., Bazzo, W A.: Desperdício na construção civil e a questão habitacional: um enfoque CTS (2001), http: / /www. oei.es/salactsi / colombobazzo.htm (accessed on: March 2013)

6. Corrêa, L.R.: Sustentabilidade na construção civil. Monografia apresentada ao Curso de Especialização em Construção Civil da Escola de Engenharia UFMG (2009), http: / / www. cecc.eng. ufmg.br/trabalhos/pg1/ Sustentabilidade\%20na\%20Constru\%E7\%E30\%20CivilL.pdf (accessed on: March 2013)

7. Esin, T., Cosgun, N.: A study conducted to reduce construction waste generation in Turkey. Building and Environment 42(4), 1667-1674 (2007)

8. FIESP/FEC. Subsídios para uma Política Industrial para a Construção Civil - Edificações. Rio de Janeiro, Relatório de Pesquisa (2008)

9. Formoso, C.T., Cesare, C.M., Lantelme, E.M.V., Soibelman, L.: As perdas na construção civil: conceitos, classificação e seu papel na melhoria do setor. MS Dissertation, Faculdade de Engenharia Civil, FEC, UNICAMP (2007)

10. Gangolells, M., Casals, M., Gassó, S., Forcada, N., Roca, X., Fuertes, A.: A methodology for predicting the severity of environmental impacts related to the construction process of residential buildings. Building and Environment 44(3), 558-571 (2009)

11. IBGE - Anuário Estatístico 2012 - Ministério do Desenvolvimento, Indústria e Comércio Exterior, Secretaria do Desenvolvimento da Produção - Brasília: SDP (2012), http: //www.desenvolvimento.gov.br/arquivos/dwnl_1337260033.pdf (accessed on: March 2013)

12. IBGE- Síntese de indicadores sociais. Estudos e pesquisas. Informação demográfica e socioeconômica, n. 5. IBGE, Rio de Janeiro (2001), http://www.ibge.gov.br/ home/estatistica/populacao/condicaodevida/indicadoresminimos/ tabela2 . shtm\#a22 (accessed on: March 2013)

13. John, V.M., Silva, V.G., Agopyan, V.: Agenda 21: uma proposta de discussão para o construbusiness brasileiro. II Encontro nacional e I Encontro Latino americano sobre edificações e comunidades sustentáveis. ANTAC/UFRGS, Canela-RS, pp. 91-98 (2001)

14. Kronka Mülfarth, R.C.: Arquitetura de baixo impacto humano e ambiental. Doctoral dissertation, São Paulo, FAU-USP (2003)

15. Lemes de Souza, V.E., et al.: Perdas de materiais nos canteiros de obras: a quebra do mito. Revista Qualidade na Construção, Sinduscon, pp. 10-15 (March 1999)

16. Mendes, R.R.C.: Investigação da mão de obra no setor da construção civil na região Central de Viçosa, MG, quanto ao treinamento e qualificação. Universidade Federal de Viçosa, Minas Gerais (2010)

17. Osmani, M., Glass, J., Price, A.: Architect and contractor attitudes to waste minimisation. Proceedings of the Institution of Civil Engineers. Waste and Resource Management 159(2), 65-72 (2006)

18. Poon, C.S., Yu, A.T.W., Jaillon, L.: Reducing building waste at construction sites in Hong Kong. Construction Management and Economics 22(5), 46-52 (2004) 
19. PSQ - Setor de Obras SINDUSCON-SP (2001), http: / /www.sindusconsp.com.br/downloads/estprod/ tecqualidade/psq.pdf (accessed on: March 2013)

20. Santos, A.R.B. dos, Carreiro, A.A.: A importância da qualificação do trabalhador para qualidade na construção civil (2010), http: / / info. ucsal . br/banmon/mostra_ dados_doc . php? Seq=324\&Pag=0\&Doc $=($ accessed on: March 2013)

21. Silva, I.G.P., Rodrigues, D.F., Pinheiro, N. V.: Cadeia Produtiva da Construção Civil: uma análise sobre a Sustentabilidade. UFPB-PRG XI Encontro de Iniciação à Docência (2008), http://www.prac.ufpb.br/anais/xenex_xienid/xi_enid/ monitoriapet / ANAIS / Area 5 / 5CCSADAMT01.pdf (accessed on: March 2013)

22. Silva, A.R., Branco, M.E.C.O.: Relato da Sustentabilidade no Setor. Revista de Administração, Contabilidade e Sustentabilidade 2(3), 33-50 (2012)

23. Teixeira, J.L.: Alfabetização de adultos: cidadania no canteiro de obras. Monografia. Universidade do Sul de Santa Catarina. Florianópolis (2006), http: / / busca.unisul.br/pdf /88037_Jose.pdf (accessed on: March 2013)

24. União Nacional da Construção. A construção no desenvolvimento sustentado. A importância da construção na vida econômica e social do país. Fundação Getúlio Vargas Projetos, São Paulo (2006)

25. Vidal, A.M., Catai, R.E., Abrahão, J.L.: Influência da experiência e da escolaridade dos trabalhadores da construção civil no aparecimento de acidentes do trabalho. Paraná: XIV SICITE - UTFPR v. I - Seção Engenharia Civil (2009)

26. Weisheng, L., Yuan, H.: A framework for understanding waste management studies in construction. Waste Management 31(6), 1252-1260 (2011)

27. World Bank Annual Report, http://web.worlabank.org/WBSITE/EXTERNAL/ EXTABOUTUS / EXTANNREP / EXTANNREP2012/0, , menUPK : 8784414 pagePK: 64168427 piPK: 64168435 theSitePK : 8784409, 00 .html (accessed on March 2012) 